\title{
Diatomae Chaetoceros ceratosporum dalam Formula Pakan Meningkatkan Respon Imun Seluler Udang Windu (Penaeus monodon Fab.)
}

\author{
Arning Wilujeng Ekawati ${ }^{1 *}$, Happy Nursyam ${ }^{2}$, Edi Widjayanto ${ }^{3}$, Marsoedi $^{2}$ \\ ${ }^{1}$ Program Doktor Ilmu Perikanan dan Kelautan, Fakultas Perikanan dan Kelautan, Universitas Brawijaya \\ ${ }^{2}$ Fakultas Perikanan dan Kelautan, Universitas Brawijaya \\ ${ }^{3}$ Fakultas Kedokteran, Universitas Brawijaya
}

\begin{abstract}
Abstrak
Penelitian ini bertujuan untuk mengetahui pengaruh dan dosis yang terbaik pada pemanfaatan diatomae Chaetoceros ceratosporum dalam formula pakan terhadap peningkatan respon imun seluler udang windu (Penaeus monodon Fab.). Penelitian ini menggunakan Rancangan Acak Lengkap (RAL) dengan 4 perlakuan dan 3 ulangan. Sebagai perlakuan adalah pemanfaatan Chaetoceros ceratosporum dalam formula pakan iso protein $39,02 \%$ dan iso energy $3,58 \mathrm{kkal} g$ pakan dengan dosis yang berbeda yaitu: A (0\%), B $(3,04 \%), C(6,08 \%)$ dan D $(9,12 \%)$. Parameter yang diamati adalah total hemosit, total diferensial hemosit (hyaline, semi granular dan granular), dan aktivitas vibriocidal. Berdasarkan hasil penelitian menunjukkan bahwa pemanfaatan diatomae Chaetoceros ceratosporum dalam formula pakan dapat meningkatkan respon imun seluler, dan dosis terbaik berkisar $5,15 \%$ $6,51 \%$.
\end{abstract}

Kata kunci: Chaetoceros ceratosporum, respon imun seluler, udang windu (Penaeus monodon Fab.)

\section{Abstract}

The aims of the experiment is to assess the effect and the best dose of Chaetoceros ceratosporum diatomae utilization in feed formula on cellular immune response of tiger shrimp (Penaeus monodon Fab.). This research applied Completely Randomized Design (CRD) with 4 treatments and 3 replications. The treatment was the use of Chaetoceros ceratosporum diatomae in feed formula (iso protein, $39.02 \%$ and iso energy $3.58 \mathrm{kcal} / \mathrm{g}$ diet) with different numbers, i.e. treatment $A=0 \%$; $B=3.04 \% ; C=6.08 \% ; D=9.12 \%$. The observed parameters were Total Haemocyte Count (THC), Total Hyaline Cells (H), Total Semi Granular cells (SG), Total Granular Cells (G), Total Plasma Protein (TPP), protease enzymes activity, superoxide anions and vibriocidal activity. The result showed that Chaetoceros ceratosporum diatomae utilization in feed formula affect the increase of cellular immune response of tiger shrimp (Penaeus monodon Fab.). The best dose ranged from $5.15 \%-$ $6.51 \%$ in feed formula.

Key words: Chaetoceros ceratosporum, cellular immune response, Penaeus monodon Fab.

\section{PENDAHULUAN}

Udang windu (Penaeus monodon Fab.) adalah termasuk krustase yang hanya memiliki sistem imun nonspesifik dalam mempertahankan tubuhnya terhadap

\footnotetext{
Alamat korespondensi: Arning Wilujeng Ekawati Email: ar_ning2000@yahoo.com

Alamat : Fakultas Perikanan dan Kelautan, Universitas Brawijaya, Malang
}

serangan patogen. Komponen sistem imun non spesifik pada udang windu meliputi fisik, seluler dan humoral [1]. Selanjutnya dijelaskan bahwa pertahanan fisik yang berperan sebagai pertahanan terluar pada udang adalah kulit, sedangkan sistem imum seluler terdiri dari Hemosit dan fixed phagocytes (sel yang tidak bergerak yang tersebar pada insang, jantung, dan jaringan pengikat). Faktor pertahanan humoral seperti protein penggumpalan, aglutinin (seperti 
lektin), enzim hidrolitik dan peptide antimikroba yang dihasilkan oleh dan akibat aksi sel imun [2].

Hemosit memegang peranan penting dalam respon seluler pertahanan tubuh udang yang meliputi fagositosis, enkapsulasi, melanisasi, cytotoksisitas dan komunikasi antar sel. Berdasarkan ada tidaknya granula sitoplasma, hemosit dibagi menjadi 3 jenis yaitu sel hyalin, sel semi granular dan sel granular $[2,3,4]$.

Peningkatan pertahanan tubuh terhadap serangan penyakit tidak hanya dapat dilakukan dengan pemberian pakan dengan komposisi nutrien yang seimbang, melainkan dapat juga disertai pemberian imunostimulan dalam pakan. Imunostimulan berhubungan langsung dengan sel sistem imun yang membuat sel tersebut lebih aktif. Pada udang windu (Penaeus monodon Fab.) dengan pemberian imunostimulan bacterin vibrio dan glucan dari yeast dapat meningkatkan aktifitas sistem pro-phenoloxidase (pro-PO) pada udang [5]. Pemberian pakan alami diatomae Chaetoceros ceratosporum juga dapat meningkatkan daya tahan larva udang windu terhadap paparan bakteri Vibrio harveyi [6,7], namun perandiatomae ini sebagai imunostimulan masih perlu diteliti lebih lanjut. Diduga $C$. ceratosporum mengandung $\beta-(1-3)$-glucan yang dapat berperan sebagai imunostimulan. Storshet $e t$ al. $[8,9]$ telah membuktikan adanya struktur $\beta$-D-(1-3)-glucan pada Chaetoceros mulleri. Selanjutnya Storshet et al. [10] juga membuktikan struktur $\beta$-D-(1-3,1-6)-glucan pada Chaetoceros debilis. Penelitianpenelitian tersebut membuktikan bahwa berbagai jenis diatomae mengandung glucan dengan struktur yang berbeda, dimana glukan ini dapat berperan sebagai imunostimulan. Oleh karena pengukuran respon imun dapat dilakukan dengan mengambil hemolim udang, dimana pada penelitian ini dilakukan pada tingkat pasca larva.

Penelitian ini bertujuan untuk mengetahui pengaruh dan dosis yang terbaik pemanfaatan diatomae Chaetoceros ceratosporum dalam formula pakan terhadap peningkatan respon imun seluler pada udang windu (Penaeus monodon Fab.).

\section{METODE PENELITIAN}

Bahan yang digunakan dalam penelitian ini antara lain: udang windu (Penaeus monodon Fabricus), bahan untuk formula pakan, Chaetoceros ceratosporum kering, bakteri Vibrio harveyi dan air laut bersalinitas $30 \mathrm{ppt}$ untuk media pembudidayaan. Bahan-bahan kimia untuk kultur pakan alami, kultur bakteri, analisis proksimat bahan pakan dan bahan kimia untuk analisis respon imun.

Peralatan yang digunakan dalam penelitian ini adalah bak kultur makanan alami, bak pemeliharaan udang beserta perlengkapan pemeliharaan (aerasi), peralatan kultur bakteri, peralatan analisis proksimat bahan pakan, pembuatan pakan, uji kualitas air.

Sesuai dengan tujuan penelitian yang ingin dicapai maka penelitian ini dilaksanakan dalam 2 tahap, yaitu Tahap I: Evaluasi komposisi kimia bahan pakan standar (tepung rebon dan tepung tapioka) dan Chaetoceros seratosporum kering. Tahap ini meliputi penentuan Kadar air dengan oven, Protein dengan metode Kjedhal, lemak dengan metode soxhlet, abu dengan metode pengabuan sampai suhu $600^{\circ} \mathrm{C}$.

Formulasi pakan untuk udang windu (Penaeus monodon Fab.) memanfaatkan Chaetoceros seratosporum yang telah diketahui komposisi kimianya dengan berbagai dosis. Tahap II adalah uji formula pakan skala Laboratorium untuk respon imun (Penaeus monodon Fab.) dengan metode eksperimen dengan rangcangan acak lengkap.

\section{Tahap I}

Membuat formula pakan dengan kadar protein $39.02 \%$ dan kadar energi $3.58 \mathrm{kkalg}^{-1}$ pakan sesuai hasil penelitian terdahulu [11] sebagai formula pakan dasar dan memanfaatkan Chaetoceros ceratosporum sebagai salah satu bahan dalam formula pakan dengan jumlah yang berbeda (Tabel 1 dan 2). Analisis proksimat ulang pakan membuat ukuran pakan sesuai ukuran udang (crumble). 
Tabel 1. Komposisi bahan pakan percobaan

\begin{tabular}{|c|c|c|c|}
\hline Analisis & Tepung Rebon & Tepung Plankton & Tepung Tapioka \\
\hline Kadar Kering (\%)* & 86,34 & 85,38 & 89,4 \\
\hline Protein $(\%)^{*}$ & 62,98 & 3,99 & - \\
\hline Lemak (\%)* & 1,59 & 0,29 & - \\
\hline Kadar Abu (\%)* & 17,05 & 66,84 & 0,59 \\
\hline Serat Kasar (\%)* & 3,01 & 2,61 & - \\
\hline BETN ** & 15,37 & 26,26 & 99,41 \\
\hline Energi (kkal/gr) ** & 327,69 & 123,65 & 397,64 \\
\hline \multicolumn{4}{|c|}{ Keterangan : } \\
\hline $\begin{array}{l}\text { : Hasil Analisis La } \\
: \text { BETN }=100- \\
: \text { Energi }=(4 \times P\end{array}$ & $\begin{array}{l}\text { n Pengujian Mutu dan } \\
\text { emak - Kadar Abu - Se } \\
9 \times \text { Lemak })+(4 \times \text { BETN }\end{array}$ & gan, Fakultas Teknologi & Ian, Universitas Brawijaya \\
\hline
\end{tabular}

Tabel 2. Formula pakan pakan percobaan udang windu (Penaeus monodon Fab.)

\begin{tabular}{lcccc}
\hline \multirow{2}{*}{ Bahan } & \multicolumn{4}{c}{ Perlakuan } \\
\cline { 2 - 5 } & $\mathbf{A ~ ( 0 \% )}$ & $\mathbf{B ~ ( 3 , 0 4 \% )}$ & $\mathbf{C ~ ( 6 , 0 8 )}$ & $\mathbf{D ~ ( 9 , 1 2 \% )}$ \\
\hline Tepung rebon & 61,96 & 61,96 & 61,96 & 61,96 \\
Tepung tapioka & 15,77 & 14,38 & 13,88 & 12,93 \\
Tepung C. ceratosporum & - & 3,04 & 6,08 & 9,12 \\
Minyak ikan & 3,75 & 3,75 & 3,75 & 3,75 \\
Minyak jagung & 6,50 & 6,50 & 6,50 & 6,50 \\
Vitamin miks & 2,70 & 2,70 & 2,70 & 2,70 \\
Mineral miks & 2,00 & 2,00 & 2,00 & 2,00 \\
CMC & $\mathbf{7 , 3 2}$ & 5,22 & 3,13 & 1,02 \\
\hline \multicolumn{1}{c}{ Total } & $\mathbf{1 0 0}$ & $\mathbf{1 0 0}$ & $\mathbf{1 0 0}$ & $\mathbf{1 0 0}$ \\
\hline
\end{tabular}

Tahap II

Uji invivo pakan percobaan

Udang windu (rata-rata $21.51 \pm 0.95$ g/ekor) diperoleh dari petani tambak dusun Kepperan, Desa Pecinan, Kecamatan Mangaran Kabupaten Situbondo dan dipilih udang yang sehat. Udang windu dipelihara pada akuarium berukuran $45 \times 45 \times 45 \mathrm{~cm}^{3}$ yang diisi air bersalinitas 30 ppt setinggi 30 $\mathrm{cm}$. Masing-masing akuarium diisi 4 ekor udang.

Pada percobaan ini menggunakan metode Rancangan Acak Lengkap (RAL) dengan perlakuan formula pakan yang memanfaatkan Chaetoceros seratosporum dalam formula pakan dengan jumlah yang berbeda (Tabel 2). Perlakuan $A=0 \% ; B=3.04 \% C=6.08 \% ; D=$ 9.12\%. Masing-masing perlakuan diulang 3 kali. Jumlah permberian pakan $3 \%$ berat badan per hari yang diberikan pada pukul 08.00 WIB, 16.00 WIB, dan 21.00 WIB, masing-masing sebanyak 30\%, 30\% dan $40 \%$ dari jumlah pemberian per hari. Lama pemeliharaan 30 hari. Penempatan akuarium percobaan dapat dilihat pada Gambar 1.

\begin{tabular}{|l|l|l|l|l|l|l|l|l|l|l|l|}
\hline D & A & C & B & A & B & C & D & B & C & A & D \\
2 & 3 & 1 & 3 & 1 & 2 & 3 & 3 & 1 & 2 & 2 & 1 \\
\hline
\end{tabular}

Gambar 1. Penempatan akuarium percobaan Keterangan: $A, B, C, D=$ perlakuan $1,2,3=$ ulangan

Setelah $P$. monodon dipelihara selama 30 hari, dilakukan pemaparan $V$. harveyi yaitu dengan cara menginjeksikan $10^{6}$ sel $\mathrm{ml}^{-1}$ bakteri sebanyak $50 \mu \mathrm{l}$ secara intramuscular /IM pada bagian ventral di antara abdomen ke 2 dan 3. Pada akhir percobaan pada masing-masing perlakuan sebelum dan sesudah infeksi Vibrio harveyi dilakukan dilakukan pengambilan hemolim udang menggunakan spet (1ml\#26) yang telah berisi antikoagulan $10 \%$ sodium citrat, $\mathrm{pH} 7.2$ dengan perbandingan hemolim dan antikoagulan 1:1 di bagian kaki jalan ketiga. Selanjutnya hemolim ini digunakan untuk pengamatan terhadap Total Hemosit (Total Haemocyte Count/THC), Differential Haemocyte Count (DHC) yang terdiri dari sel hyalin $(H)$, sel semi granular (SG) dan sel granular (G); dan Aktivitas Vibriocidal. 
Kultur Bakteri Vibrio harveyi

Sterilisasi ose lengkung dengan pemanasan di atas bunsen hingga pijar. Setelah ose dipastikan dingin diambil bakteri Vibrio dari stock dengan cara menyentuhkan ujung ose pada stock. Goreskan di permukaan media TCBSA, dengan metode streaking kuadran untuk mendapatkan koloni terpisah. Inkubasikan media $30^{\circ} \mathrm{C}$ selama 24 jam. Koloni murni yang tumbuh diidentifikasi ulang untuk memastikan spesies bakteri. Setelah terbukti spesies Vibrio harveyi, dilakukan kultur pengkayaan untuk memproduksi dalam jumlah yang besar.

\section{Prosedur Pengkayaan}

Dengan ose steril ambil koloni murni, masukkan ke dalam erlemeyer yang berisi media cair TSB+. Tutup erlemeyer kembali dengan kapas steril, masukkan ke dalam shaker waterbath. Inkubasikan pada suhu $30^{\circ} \mathrm{C}$ dengan kecepatan shaking 100 rpm selama 2 x 24 jam. Amati hasil kultur pastikan tidak ada kontaminasi dengan pewarnaan gram dan dilihat di bawah mikroskop. Kemudian kepadatan bakteri kultur ditera dengan Mc Farland. Dari hasil pengukuran OD (Optical Dencity) dilakukan pengenceran sesuai dengan kepadatan bakteri yang diinginkan.

\section{Persiapan Plasma Supernatant (PS) dan Haemocyte Lysate Supernatant (HLS)}

Untuk mendapatkan HLS dilakukan menggunakan metode Sahoo et al. [12]. Hemolim sebanyak $200 \mu \mathrm{L}$ diambil menggunakan mikropipet kemudian masukkan ke tabung eppendorf $1,5 \mathrm{ml}$. Hemolim selanjutnya disentrifuse pada 2.300 rpm suhu $4^{\circ} \mathrm{C}$ selama 10 menit. Supernatan diambil sebagai plasma supernatant (PS), kemudian pelet ditambahkan 0,01 M Phosfat Buffer Saline (PBS) pH 7,0 sebanyak $100 \mu \mathrm{L}$ dan disentrifuse kembali pada 2.300 rpm selama 10 menit. Supernatan dibuang, pelet yang didapatkan diresuspensi dengan 0,01 M PBS pH 7,0 sebanyak $1 \mathrm{ml}$ dilanjutkan dengan homogenisasi dan sentrifuse pada $4.000 \mathrm{rpm}$ suhu $4^{\circ} \mathrm{C}$ selama 30 menit. PS dan HLS yang didapatkan disimpan pada suhu $4^{\circ} \mathrm{C}$ sebelum digunakan untuk uji aktivitas vibriocidal.

Hemosit

Total Haemocyte Count (THC) dihitung menggunakan haemocytometer dengan bantuan mikroskop cahaya dengan pembesaran $400 \times$ sebagai berikut:

$\mathrm{THC}=\frac{\text { Jumlah sel yang díhitung }}{\text { jumlah bìdang pandang }} \times 10^{4} \times$ faktor pengencer

Pengamatan jumlah sel differensial hemosit (hyalin, semi granular dan granular) dalam persentase berdasarkan kriteria morfologi dengan menggunakan mikroskop cahaya perbesaran $1.000 \times$ [2].

\section{Aktivitas Vibriocidal}

Aktifitas vibriocidal diukur menurut prosedur modifikasi [13]. Vibrio harveyi dikultur pada Tryptic Soy Broth (TSB) pada suhu $30^{\circ} \mathrm{C}$ selama 24 jam. Bakteri disentrifuse kecepatan $4.000 \mathrm{rpm}$, selama 20 menit pada suhu $4^{\circ} \mathrm{C}$ dan dicuci dengan PBS dan diresuspensi sampai volume semula. $1 \mu \mathrm{l}$ suspensi bakteri ditambahkan ke $100 \mu \mathrm{l}$ PS atau HLS udang kemudian diinkubasi selama 1 jam. Selanjutnya diencerkan sampai 100 kali dengan PBS dan dikultur pada media agar (TSA) setelah 24 jam pada $30^{\circ} \mathrm{C}$, koloni yang tumbuh dihitung. Persentase penghambatan dihitung dengan rumus:

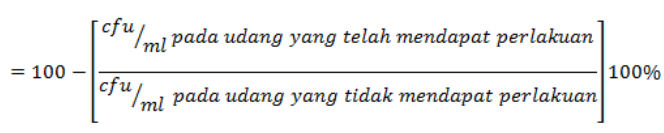

Data total Hemosit, sel hyalin, sel semi granular, sel granular dan aktivitas vibriocidal, dianalisis menggunakan sidik ragam. Responnya diuji dengan uji F [14].

\section{HASIL DAN PEMBAHASAN}

Total Hemosit (Total Haemocyte Count/THC)

Berdasarkan hasil pengamatan Total Hemosit udang windu (Penaeus monodon Fab.) setelah dipelihara selama 30 hari dengan pakan percobaan sebelum dan sesudah diinfeksi $V$. harveyi adalah seperti yang tertera pada Tabel 3. 
Tabel 3. Total hemosit udang windu (Penaeus monodon Fab.) pasca diberi pakan percobaan sebelum dan

\begin{tabular}{ccc} 
& \multicolumn{2}{c}{ sesudah diinfeksi V. harveyi } \\
\hline \multirow{2}{*}{ Perlakuan } & \multicolumn{2}{c}{ Total Hemosit $\left(\mathbf{1 0}^{\mathbf{6}}\right.$ sel $\left.\mathbf{~}^{-1}\right)$} \\
\cline { 2 - 3 } & Sebelum infeksi . harveyi & Sesudah infeksi . harveyi \\
\hline A & $35,40 \pm 4,15 \mathrm{a}$ & $20,93 \pm 2,03 \mathrm{a}$ \\
B & $60,75 \pm 3,030 \mathrm{c}$ & $48,37 \pm 2,36 \mathrm{c}$ \\
C & $66,85 \pm 0,30 \mathrm{~d}$ & $59,03 \pm 0,20 \mathrm{~d}$ \\
D & $50,98 \pm 2,30 \mathrm{~b}$ & $39,88 \pm 2,39 \mathrm{~b}$ \\
\hline
\end{tabular}

Keterangan: Notasi yang sama menunjukkan tidak ada perbedaan, sedangkan notasi yang berbeda menunjukkan ada perbedaan antar perlakuaan pada taraf kepercayaan $95 \%$.

Dari Tabel 3 terlihat bahwa perlakuan jumlah C. ceratosporum dalam formula pakan memberikan pengaruh terhadap total hemosit udang windu yang dipelihara selama 30 hari dengan pakan percobaan, sebelum diinfeksi dan sesudah diinfeksi $V$. harveyi. Masing-masing antar perlakuan $A, B, C$, dan D berbeda .

Hubungan antara jumlah $C$. ceratosporum dalam formula pakan $(X)$ dengan total hemosit udang windu $(Y)$ sebelum diinfeksi berpola kuadratik dengan persamaan:

$$
Y=-1,115 X^{2}+11,90 X+35,26 ; R^{2}=0,95
$$

Dari persamaan tersebut diperoleh bahwa jumlah $C$. ceratosporum yang menghasilkan total hemosit tertinggi sebesar $67,05 \times 10^{6}$ sel/ml pada udang windu adalah 5,34\% dalam formula pakan.

Hubungan antara jumlah $C$. ceratosporum dalam formula pakan (X) dengan total hemosit udang windu $(Y)$ sesudah diinfeksi berpola kuadratik dengan persamaan:

$$
Y=-1.260 X^{2}+13.71 X+20.28 ; R^{2}=0,90
$$

Dari persamaan tersebut diperoleh bahwa jumlah C.ceratosporum dalam formula pakan yang menghasilkan total hemosit tertinggi sebesar $57,59 \times 10^{6} \mathrm{sel} / \mathrm{ml}$ pada udang windu adalah $5.44 \%$.

\section{Total Hemosit Differensial (Differential Haemocyte Count/DHC)}

Berdasarkan hasil pengamatan Total Hemosit Differensial (sel hyalin, semi granular dan granular) pada udang windu (Penaeus monodon Fab.) setelah dipelihara selama 30 hari dengan pakan percobaan sebelum dan sesudah diinfeksi $V$. harveyi adalah seperti yang tertera pada Tabel 4.

Dari Tabel 4 terlihat bahwa perlakuan jumlah $C$. ceratosporum dalam formula pakan tidak memberikan pengaruh terhadap total sel hyalin udang windu yang dipelihara selama 30 hari dengan pakan percobaan, sebelum diinfeksi dan sesudah diinfeksi $V$. harveyi.

Tabel 4. Total sel Hyalin (H), Semi Granular(SG) dan Granular (G) udang windu (Penaeus monodon Fab.) pasca diberi pakan percobaan sebelum dan sesudah diinfeksi $V$. harveyi

\begin{tabular}{lcccc}
\hline \multicolumn{1}{c}{$\begin{array}{c}\text { Hemosit } \\
\text { Differensial }\end{array}$} & A & B & C & D \\
\cline { 2 - 5 } & & & & \\
\hline Sebelum diinfeksi & $30 \pm 5 \mathrm{a}$ & $26,33 \pm 3,21 \mathrm{a}$ & $23 \pm 1,73 \mathrm{a}$ & $26,67 \pm 1,15 \mathrm{a}$ \\
Total sel H (\%) & $26,33 \pm 4,16 \mathrm{c}$ & $13,33 \pm 5,69 \mathrm{a}$ & $11,00 \pm 2,00 \mathrm{a}$ & $20,00 \pm 1,73 \mathrm{~b}$ \\
Total sel SG (\%) & $43,67 \pm 3,51 \mathrm{a}$ & $60,33 \pm 2,52 \mathrm{a}$ & $66,00 \pm 1,00 \mathrm{~b}$ & $53,33 \pm 2,89 \mathrm{a}$ \\
Total sel G (\%) & & & & \\
\hline Sesudah diinfeksi & $28,67 \pm 5,03 \mathrm{a}$ & $35,00 \pm 3,00 \mathrm{a}$ & $32,67 \pm 2,52 \mathrm{a}$ & $30,00 \pm 2,00 \mathrm{a}$ \\
Total sel H (\%) & $35,33 \pm 5,13 \mathrm{c}$ & $10,00 \pm 5,00 \mathrm{a}$ & $3,00 \pm 2,65 \mathrm{a}$ & $19,67 \pm 0,58 \mathrm{~b}$ \\
Total sel SG (\%) & $36.00 \pm 1.73 \mathrm{a}$ & $55.00 \pm 2.00 \mathrm{~b}$ & $64,33 \pm 0,58 \mathrm{c}$ & $50,67 \pm 1,15 \mathrm{~b}$ \\
Total sel G (\%) & & & & \\
\hline
\end{tabular}


Total sel semi granular udang windu sebelum iinfeksi $V$. harveyi pada perlakuan $\mathrm{A}$ berbeda dengan $B, C$, dan $D$, namun $B$ dan $C$ tidak berbeda.

Hubungan antara jumlah $C$. ceratosporum dalam formula pakan (X) dengan total sel semi granular udang windu (Y) sebelum diinfeksi berpola kuadratik dengan persamaan:

$$
Y=0,595 X^{2}-6,129 X+26,36 ; R^{2}=0,76
$$

Dari persamaan tersebut diperoleh bahwa jumlah C. ceratosporum dalam formula pakan yang menghasilkan total sel semi granular terendah sebesar $10,58 \%$ pada udang windu adalah 5,15\%.

Hubungan antara jumlah $C$. ceratosporum dalam formula pakan $(X)$ dengan total sel semi granular udang windu (Y) sesudah diinfeksi berpola kuadratik dengan persamaan:

$$
Y=1,136 X^{2}-12,13 X+35,60 ; R^{2}=0,76
$$

Dari persamaan tersebut diperoleh bahwa jumlah C.ceratosporum dalam formula pakan yang menghasilkan total sel semi granular terendah sebesar 3,18 \% pada udang windu adalah 5,34\%.

Total sel granular udang windu sebelum diinfeksi $V$. harveyi pada perlakuan $C$ berbeda dengan $B, C$, dan $D$, sedangkan $A, B$ dan $D$ tidak berbeda.

Hubungan antara jumlah $C$. ceratosporum dalam formula pakan (X) dengan total sel granular udang windu (Y) sebelum diinfeksi berpola kuadratik dengan persamaan:

$$
Y=-0,793 X^{2}+8,377 X+43,3 ; R^{2}=0,99
$$

Dari persamaan tersebut diperoleh bahwa jumlah C. ceratosporum dalam formula pakan yang menghasilkan total sel granular tertinggi sebesar $65,41 \%$ pada udang windu adalah $5,28 \%$.

Total sel granular udang windu sesudah diinfeksi $V$. harveyi pada perlakuan $C$ berbeda dengan B, C, dan D, namun B dan D tidak berbeda.

Hubungan antara jumlah $C$. ceratorporum dalam formula pakan (X) dengan total sel granular udang windu (Y) sesudah diinfeksi berpola kuadratik dengan persamaan:

$$
Y=-0,833 X^{2}+9,813 X+35,33, R^{2}=0,92
$$

Dari persamaan tersebut diperoleh bahwa jumlah C.ceratosporum dalam formula pakan yang menghasilkan total sel granular tertinggi sebesar $62,58 \%$ pada udang windu adalah 5,55\%.

\section{Aktivitas Vibriocidal}

Berdasarkan hasil uji aktivitas vibriocidal pada Plasma Supernatan (PS) dan Haemocyte Lysate Supernatant (HLS) udang windu (Penaeus monodon Fab.) setelah dipelihara selama 30 hari dengan pakan percobaan dapat dilihat pada Tabel 5.

Dari Tabel 5 terlihat bahwa perlakuan jumlah C. ceratosporum dalam formula pakan memberikan pengaruh terhadap aktivitas vibriocidal pada PS dan HLS udang windu yang dipelihara selama 30 hari dengan pakan

\begin{tabular}{|c|c|c|}
\hline \multirow{2}{*}{ Perlakuan } & \multicolumn{2}{|c|}{ Aktivitas Vibriocidal (\%) } \\
\hline & PS & HLS \\
\hline$A(0 \%)$ & Oa & Oa \\
\hline B $(3,04 \%)$ & $68,12 \pm 0,96 b$ & $77,71 \pm 5,79 b$ \\
\hline$C(6,08 \%)$ & $84,85 \pm 3,11 c$ & $88,35 \pm 1,19 c$ \\
\hline $\mathrm{D}(9,12 \%)$ & $69,39 \pm 1,47 c$ & $84,14 \pm 0,72 b$ \\
\hline
\end{tabular}
percobaan.

Tabel 5. Aktivitas Vibriocidal pada PS dan HLS udang windu (Penaeus monodon Fab.)

Aktivitas vibriocidal pada PS udang windu menunjukkan bahwa perlakuan $C$ berbeda dengan A dan B tetapi tidak berbeda dengan $D$, sedangkan pada HLS perlakuan $C$ berbeda dengan $A, B$ dan $D$, namun $B$ dan $D$ tidak berbeda.

Hubungan antara jumlah $C$. ceratorporum dalam formula pakan $(X)$ dengan aktivitas vibriocidal pada PS udang windu $(\mathrm{Y})$ berpola kuadratik dengan persamaan:

$$
Y=-2,263 X^{2}+28,04 X+0,956 ; R^{2}=0,99
$$

Dari persamaan tersebut diperoleh bahwa jumlah C.ceratosporum dalam formula pakan yang menghasilkan aktivitas vibriocidal tertinggi sebesar $87,85 \%$ pada PS udang windu adalah 6,20\%.

Hubungan antara jumlah C. ceratorporum dalam formula pakan (X) dengan aktivitas vibriocidal pada HLS udang windu (Y) berpola kuadratik dengan persamaan:

$$
Y=-2,216 X^{2}+28,86 X+2.610 ; R^{2}=0,97
$$


Dari persamaan tersebut diperoleh bahwa jumlah C.ceratosporum dalam formula pakan yang menghasilkan aktivitas vibriocidal tertinggi sebesar $96,60 \%$ pada HLS udang windu adalah $6,51 \%$.

\section{Pembahasan}

Total hemosit udang windu (Tabel 4) menunjukkan bahwa perlakuan pemanfaatan $C$. ceratosporum dalam formula pakan lebih tinggi daripada tanpa C. ceratosporum. Berdasarkan hasil penelitian hemosit udang windu tertinggi sebesar $67,05 \times 10^{6} \mathrm{sel} / \mathrm{ml}$ diperoleh pada perlakuan pemanfaatan $C$. ceratosporum dalam formula pakan sebesar 5,34 \%. Total hemosit yang diperoleh pada penelitian ini sesuai dengan yang diperoleh van de Braak et al. [15] yaitu sebesar $50,9 \times 10^{6} \pm 17,7 \times 10^{6} \mathrm{sel} / \mathrm{ml}$. Hasil ini sejalan dengan penelitian Yeh et al. [16] yang menunjukkan bahwa terjadi peningkatan jumlah hemosit pada udang putih (Litopenaeus vannamei) pasca pemberian ekstrak Sargassum duplicatum baik melalui perendaman maupun injeksi.

Hemosit disintesis oleh oleh jaringan hematopoietic yang merupakan sepasang epigastric nodule. Produksi tersebut dilakukan untuk mencapai keadaan homeostatis pasca introduksi imunostimulan. Jaringan tersebut terletak tepat di bagian dorsal pada lambung bagian depan (anterior stomach), merupakan tempat sintesa hemocyanin. Bila imunostimulan dapat meningkatkan hemocyanin, maka secara langsung akan terjadi pula peningkatan hemosit [17].

Setelah uji tantang dengan bakteri Vibrio harveyi selama 24 jam, terjadi penurunan jumlah hemosit pada semua perlakuan dengan rerata untuk perlakuan pemanfaatan $C$. ceratosporum dalam formula pakan lebih tinggi daripada tanpa C. ceratosporum. Nilai tertinggi diperoleh pada perlakuan $5,44 \%$ dengan total hemosit sebesar $57,59 \times 10^{6} \mathrm{sel} \mathrm{ml}^{-1}$. Hal ini sesuai dengan van de Braak [2] bahwa total hemosit menurun setelah diinfeksi bakteri Vibrio anguillarum. Selama periode pembersihan bakteri dari sirkulasi, THC lebih rendah, hal ini menandakan adanya aktivitas pertahanan.

Jumlah hemosit udang dapat menurun apabila kondisi lingkungan memburuk, misalnya rendahnya kandungan oksigen terlarut, suhu dan salinitas, atau terdapatnya serangan patogen [1]. Selanjutnya hemosit baru perlu pengganti dan diproduksi secara proporsional dan diyakini bahwa hemosit dikeluarkan secara kontinyu, walau pada laju yang bervariasi, dari jaringan hematopoeietik. Jaringan tersebut telah diidentifikasi pada beberapa spesies krustase.

Saat terjadinya serangan patogen, sel hemosit akan melakukan proses degranulasi, cytotoxicity dan lisis terhadap material tersebut. Dengan demikian jumlah sel hemosit yang beredar dalam hemolim akan terlihat menurun. Hasil proses degranulasi adalah pelepasan peroxinectin yang akan memicu munculnya fagositosis [17].

Lectin atau agglutinin adalah protein pada hemolim yang memiliki peranan penting saat terdapatnya antigen yang masuk ke dalam tubuh. Komponen ini akan berikatan dengan karbohidrat yang terdapat pada dinding sel patogen atau benda asing yang disebut sebagai aglutinasi. Reaksi akan diikuti dengan eliminasi benda asing tersebut melalui proses fagositosis, melanisasi oleh enzim phenoloksidase dan lonjakan respirasi (respiratory burst) [1].

Hemosit memiliki peran yang penting pada sistem pertahanan imunitas. Pertama, hemosit menghancurkan partikel/benda asing dalam haemacoel melalui fagositosis, enkapsulasi, agregat nodulasi, melanisasi, cytotoksisitas dan komunikasi antar sel [3, 4,18]. Kedua, hemosit memiliki andil dalam penanganan luka lewat reaksi seluler dan yang mengawali proses koagulasi dengan membawa dan melepaskan sistem prophenoloksidase (proPO). Ketiga, hemosit terlibat dalam pembentukan dan perombakan molekul-molekul penting dalam hemolim seperti $\alpha_{2}$-macroglobulin $\left(\alpha_{2} M\right)$, agglutinin dan peptide antimicrobial.

Pada kasus ini, udang yang diberi pakan yang mengandung $C$. ceratosporum terbukti meningkatkan jumlah THC udang windu. Seiring dengan peningkatan total hemosit udang, sistem kekebalan tubuh udang juga akan meningkat sehingga tingkat serangan infeksi bakteri $V$. harveyi dapat tereduksi. Namun demikian, ketika pemberian pakan yang mengandung $C$. ceratosporum melebihi batas kemampuan tubuh untuk meresponnya justru akan menjadi imunostresor yang dapat menurunkan sistem kekebalan tubuh udang.

Berdasarkan pengamatan total differensial hemosit (Tabel 5) terlihat bahwa secara keseluruhan nilai paling tinggi adalah sel granular, diikuti Sel hyalin dan sel semi granular. Total sel Hyalin untuk semua perlakuan tidak berbeda. Total sel semi granular terendah sebesar $10,58 \%$ pada perlakuan pemanfaatan $C$. ceratosporum sebesar $5,15 \%$, sedangkan total 
sel granular tertinggi sebesar $65,41 \%$ diperoleh pada perlakuan pemanfaatan $C$. ceratosporum sebesar 5,34\%.

Setelah 24 jam diinfeksi dengan $V$. harveyi sejalan dengan penurunan total hemosit, total differensial hemosit juga mengalami penurunan. Seperti halnya sebelum diinfeksi, total sel Hyalin untuk semua perlakuan tidak berbeda. Total sel semi granular terendah sebesar 3,18 \% pada perlakuan pemanfaatan C.ceratosporum sebesar $5,34 \%$, sedangkan total sel granular tertinggi sebesar 62,58 \%diperoleh pada perlakuan pemanfaatan C.ceratosporum sebesar 5,55\%.

Hal tersebut menandakan bahwa yang banyak berperan adalah sel granular dibandingkan sel hyalin dan sel semigranular. Sel semi granular merupakan pematangan dari sel hyalin yang ketika terjadi serangan patogen maka yang berperan pertama adalah sel hyalin, sehingga sel ini tidak berkembang menjadi sel semi granular dan terlihat penurunan jumlah sel semi granular yang terdapat dalam hemosit [2]. Sel semigranular berperan utama dalam proses enkapsulasi dan sedikit dalam proses fagositosis.

Sel semi granular dikarakteristikkan dengan terdapatnya granula pada sitoplasma. Sel ini mampu merespon polisakarida dari dinding sel bakteri atau $\beta$-glucan yang berasal dari jamur. Sel semi granular ini dapat melakukan proses enkapsulasi dan sedikit berperan dalam proses fagositosis [3]. Enkapsulasi adalah merupakan reaksi pertahanan melawan partikel dalam jumlah yang besar dan tidak mampu difagosit oleh sel hemosit [19].

Fungsi sel granular lebih pada proses menghasilkan enzim phenoloksidase yang memiliki peranan penting dalam sistem pertahanan non spesifik. Supamattaya [1] menjelaskan granula pada sel granular hemosit terdiri dari propenoloksidase. Dalam aktivasi prophenoloksidase (proPO) akan membebaskan suatu enzim dari sel granular. Sistem ini juga dipacu oleh adanya komponen mikrobial seperti $\beta$-glucan.

Proses prophenoloksidase bertanggung jawab terhadap produksi dan sekresi metabolit toksik seperti quinon. Produk akhir dari sistem ini adalah munculnya blackish nodules yang biasanya berada di sekitar insang atau eksoskeleton. Saat terjadinya serangan patogen, sel granular dan semi granular akan melakukan proses degranulasi, cytotoxicity dan lisis terhadap material tersebut dengan demikian jumlah sel granular yang beredar dalam hemolim akan mengalami penurunan. Hasil proses degranulasi adalah pelepasan peroxinectin yang akan memicu munculnya fagositosis.

Sejalan dengan tingginya total hemosit pada udang windu diikuti dengan tingginya Aktivitas vibriocidal pada PS dan HLS udang windu (Tabel 5). Nilai tertinggi sebesar $87,85 \%$ pada PS udang windu diperoleh pada perlakuan pemanfaatan $C$. ceratosporum sebesar $6,20 \%$, sedangkan Nilai tertinggi sebesar $96,60 \%$ pada HLS udang windu diperoleh pada perlakuan pemanfaatan $C$. ceratosporum sebesar 6,51\%. Hal ini menunjukkan bahwa dengan semakin meningkatnya total hemosit maka aktivitas vibriosidal juga meninggkat. Hasil ini sesuai dengan hasil penelitian Devaraja [5] yang membuktikan bawa pemanfaatan $0,2 \%$ glucan dari yeast $+10 \%$ bacterin melalui pakan dapat meningkatkan aktivitas vibriocidal pada udang windu, namun pada dosis yang melebihi nilai tersebut hasilnya menurun. Pada penelitian lain diperoleh informasi bahwa penggunaan estrak $\beta$ glukan dari Saccharomyces cerevisiae TISTR 5088 dan ditambahkan ke dalam pakan dapat meningkatkan total hemosit (THC), aktivitas vibriocidal dan ketahanan terhadap serangan bakteri [20].

\section{KESIMPULAN}

Berdasarkan hasil penelitian dapat disimpulkan bahwa pemanfaatan diatomae Chaetoceros ceratosporum dalam formula pakan dapat meningkatkan respon imun seluler, dan dosis terbaik berkisar 5,15\%-6,51\% dalam formula pakan.

\section{DAFTAR PUSTAKA}

[1] Supamattaya K., Chittiwan N. and Boonyaratpalin M. 2000. Immunological factors in black tiger shrimp, Penaeus monodon Fabricus. http://aquafeed.com /docs/ns/Supamattayaetal.pdf.

[2] Van de Braak C.B.T. 2002. Haemocytic defence in black tiger shrimp Penaeus monodon. PhD Thesis. Wageningen University. The Netherland. 159pp.

[3] Johansson M.W., Keyser P., Sritunyalucksana K. and Söderhäll K. 2000. Crustacean haemocytes and haematopoiesis. Aquaculture, 191:45-52.

[4] Rodriguez J., and Le Moullac G. 2000. State of the art of immunological tools and health control of Penaeid Shrimp. Aquaculture, 191: 109-119.

[5] Devaraja T.N., Otta S.K., Shubha G., Karunasagar I., Tauro P., Karunasagar I. 
1998. Immunostimulation of shrimp through oral administration of Vibrio bacterin and Yeast Glucan. Flegel T.W. (Ed.). Advances in Shrimp Biotechnology. National Center for Genetic Engineering and Biotechnology, Bangkok. 167-170.

[6] Kartikaningsih H., Ekawati A.W., Sukoso, Haryanti dan Zafran. 1999. Penggunaan fitoplankton Chaetoceros ceratosporum kering untuk menghambat perkembangan bakteri Vibrio harveyi. ARMP. 1998/1999.

[7] Kartikaningsih H., Ekawati A.W., Haryanti dan Rosa. 2000. Penggunaan fitoplankton Chaetoceros ceratosporum kering untuk menghambat perkembangan bakteri Vibrio harveyi. ARMP. 1999/2000.

[8] Storseth T.R., Hansen K., Skejermo J. and Krane J. 2004. Characterization of a $\beta$-D-(13)-glucan from marine diatom Chaetoceros mulleri by high-resolution magic-angle spinning NMR spectroscopy on whole algal cells. Carbohydrate Res., 339:421-424

[9] Storseth T.R., Hansen K., Reitan K.I. and Skejermo J. 2005. Sructural characterization of $\beta$-D-(1-3)-glucans from different growth phases of the marine diatoms Chaetoceros mulleri and Thalasiosira weissflogii. Carbohydrate Res., 240: 1159-1164.

[10] Storseth T.R., Kirkvold S., Skjermo J. and Reitan K.I. 2006. A branced $\beta-D-(1-3,1-6)-$ glucan from the marine diatom Chaetoceros debilis (Bacillariophyceae) characterized by NMR. Carbohydrate Res., 341: 2108-2114.

[11] Ekawati A.W. 1990. Pengaruh kadar protein pakan terhadap pertumbuhan pascalarva udang windu (Penaeus monodon Fab.). Tesis. FPS, Institut Pertanian Bogor, Bogor. 71 hal.

[12] Sahoo B., Sethi S., Mishra B.K. and Das B.K. 2005. Effects elecitors on prophenonoloxidase and superoxide anion activities of freshwater prawn, Macrobrachium malcolmsonii. Asian Fish. Sci., 18:345-353.

[13] Adams A. 1991. Response of penaeid shrimp to exposure to vibrio species. Fish and shellfish Immunology, 1: 59-70.

[14] Snedecor G.W. and Cochran W.G. 1980. Statistical methods ( $7^{\text {th }}$ Ed.). The lowa State Univ. Press. lowa. 507p.

[15] Van de Braak K., Faber F. and Boon J.H. 1996. Cellular and humoral characteristisc of Penaeus monodon (Fabricius, 1798) haemolymph. Comp. Haematol. Internat., 6: 194-203.
[16] Yeh S.T., Chiu S., Lee C. and Jiann C. 2006. Administration of hot-water extract of brown seaweed Sargassum duplicatum Via immersion and injection enhances the immune resistance of white shrimp Litopenaeus vannamei. Fish and Shellfish Immunology, 20: 332-345.

[17] Effendy S., Alexander R. dan Akbar T. 2004. Peningkatan haemosit benur udang windu (Penaeus monodon Fabricus) pasca perendaman ekstrak ragi roti (Saccharomyces cerevisiae) pada konsentrasi yang berbeda. Jurnal Sains dan Teknologi, 14(2): 46-53.

[18] Sordehall K. and Cerenius L. 1998. Role of prophenoloxidase-activating system in invertebrate immunity. Current Opinion in Immunology, 10: 23-28.

[19] Danwattananusorn T. 2009. Studies on peptidoglycan induced immune-related genes of Kuruma Shrimp Marsupenaeus japonicus. PhD Thesis. Graduate School of Marine Science and Technology Tokyo University of Marine Science and Technology Doctoral Course of Applied Marine Biosciences. 7-18.

[20] Sittipun M., Hangpongkittikul A. and Supamattaya K. 2000. Immunostimulant and vaccination in Black Tiger Shrimp, Penaeus monodon Fabricius: I. Extraction of beta-glucan from yeast and it application in Penaeus monodon Fabricius. Songklanarin J. Sci. Technol., 22 (Suppl.): 653-662. 